\title{
Influence of Flow Shallowness on Scour Depth at Semi-Integral Bridge
}

\section{Piers}

\author{
Shatirah Akib ${ }^{1, a}$, Faridah Othman ${ }^{1, b}$, Mohammad Sholichin ${ }^{2, c}$, \\ Moatasem M. Fayyadh ${ }^{1, d}$,S.M. Shirazi ${ }^{1, e}$, Budhi Primasari ${ }^{1, f}$ \\ 1) Department of Civil Engineering, Faculty of Engineering, University of Malaya, \\ 50603 Kuala Lumpur, Malaysia. \\ ${ }^{2)}$ Department of Water Resources Engineering, Faculty of Engineering, University of \\ Brawijaya, Malang 65145, Indonesia \\ a shatirah@um.edu.my, b faridahathman@um.edu.my, \\ c mochsholichin@yahoo.com, ${ }^{d}$ moatasem.m.f@gmail.com, ${ }^{\mathrm{e}}$ smshirazi@gmail.com
}

Keywords: Flow shallowness, semi-integral bridge, scour, pier

\begin{abstract}
The paper presents the experimental study on the effect of flow shallowness on the scouring at semi-integral bridge piers. The experimental work was conducted in the Hydraulic Laboratory of University of Malaya. Out of 1020 data collected in the flow shallowness and time evolution experiments, 60 data were chosen at maximum scour depth to be analyzed. 30 data for sediment size of $d_{50}=0.8 \mathrm{~mm}$ and 30 data for $\mathrm{d}_{50}=0.26 \mathrm{~mm}$ were taken at each side of the piers. The results showed that similar trend was produced for both sediment sizes, the depth of scour increased with the flow depth. Almost all of the data plotted gave the best correlation coefficient. The scour depth at the left and right side of the pier were almost averaged.
\end{abstract}

\section{Introduction}

Integral bridge is designed by structural engineers in Malaysia to reduce initial construction cost, long-term maintenance expenses, substructure design, resistance to accidental and seismic loadings, torsional restraint of deck at support, faster construction, tolerance requirements reduced and greater end span ratio ranges[1]. Many researches have studied the local scour phenomenon by experimentally or theoretically using vertical bridge piers and considered a number of parameters affecting the phenomenon. Local scour occurs when there is an obstruction of flow that caused by the bridge foundation. The local flow field near the bridge piers is stay enough to removed bed material to forming the scour to the structure. The process of local scour is depending on time, flow shallowness, flow intensity, sediment courseness and others. Equilibrium will be achieved through the erosion of the flow boundary between the erosion of the flow and resistance flow of the sediment. In sand, the live bed scour acts faster than the clear water scour to attain the final depth scour. Raudkivi [2] conducted several studies to study the effects of scour on pier and abutment at bridge foundations. Ali and Karim[3], Ansari et al [4], Coleman [5], focused the local scour study particularly on piers. Akib et al [6] studied effects of scour particularly at semi-integral bridge piers and pile groups. Flow shallowness,y respected to the depth of scour, ds with the width of the effect of the pier, $b$ is presented in Fig.1. 


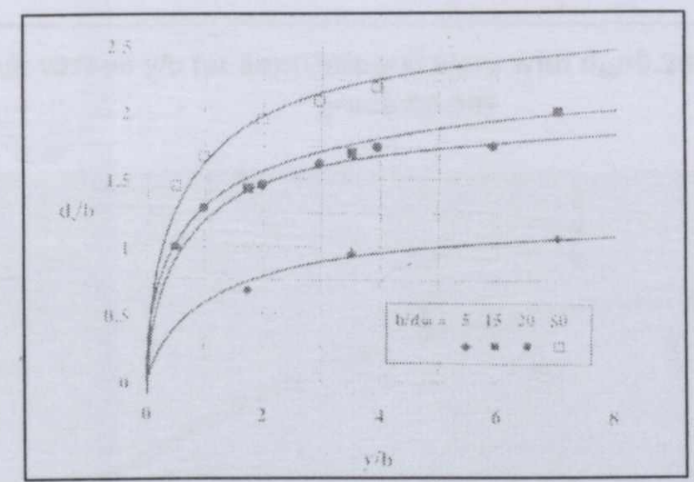

Fig. $1 \mathrm{ds} / \mathrm{b}$ with respect to $\mathrm{y} / \mathrm{b}$ on local scour at piers.

(Melville and Coleman,1999).

\section{Experimental Work}

The model was located at the last one fourth of the recirculating flume to achieve a well established flow that was at 4 meter from the downstream in the flume. A control block, which was constructed from a piece of Perspex with height of $13 \mathrm{~cm}$, was placed at the upstream and downstream of the sediment bed in the main channel to control the sediments. Water flows were recirculated in the flume. Six points of velocity measurement were taken for every experiment. Scour depth was measured at the right and left sides of the piers. The bed sediment was leveled and compacted in flume. For this experiment, five water levels were set. For every velocity, the experiment was conducted for 24 hours. The scour depths were recorded every 1 minute for 10 times followed by 10 minutes for 10 times, 5 times for every 100 minutes and the last reading after 24 hours. The velocity and water depth were measured. The developments of scour at the piers were measured for sediment sizes $d_{50}=0.8 \mathrm{~mm}$ and $d_{50}=0.26 \mathrm{~mm}$ (Fig. 2).

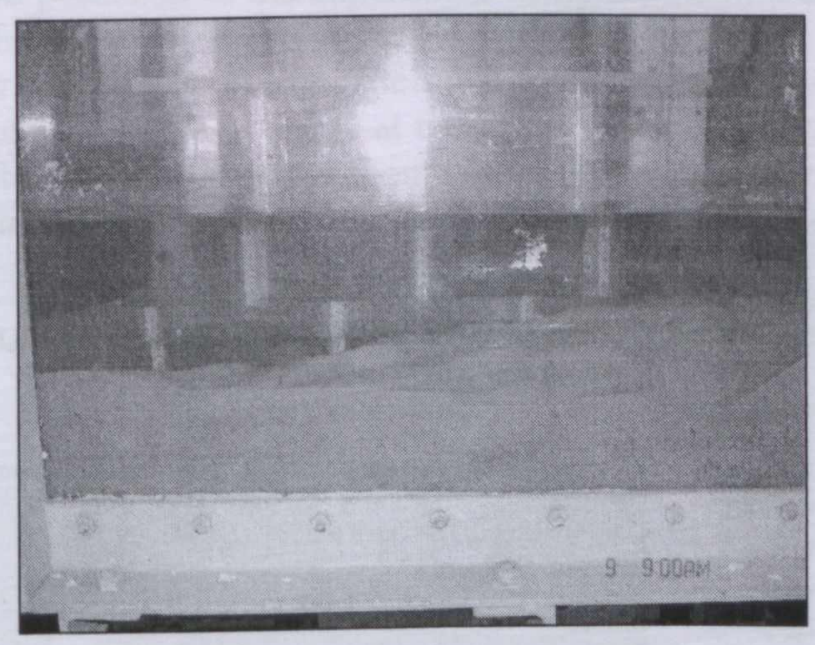

Fig. 2 Scour formed at the piers during the experiments. Dunes were formed at the downstream of the main channel.

\section{Results and Discussion}

For complex piers, the flow parameters that affect the equilibrium scour depth include relative value of flow depth and pier diameter. The relative scour depth, $d_{s} / b$, was plotted against the relative water depth, $y_{s} / b$, for different discharges in Fig. 3. From the data plotted, it is shown that ds/b generally increased with $y / b$. The results seem reasonable because equilibrium scour depth increases with approach flow velocity and pier diameter [7]. 

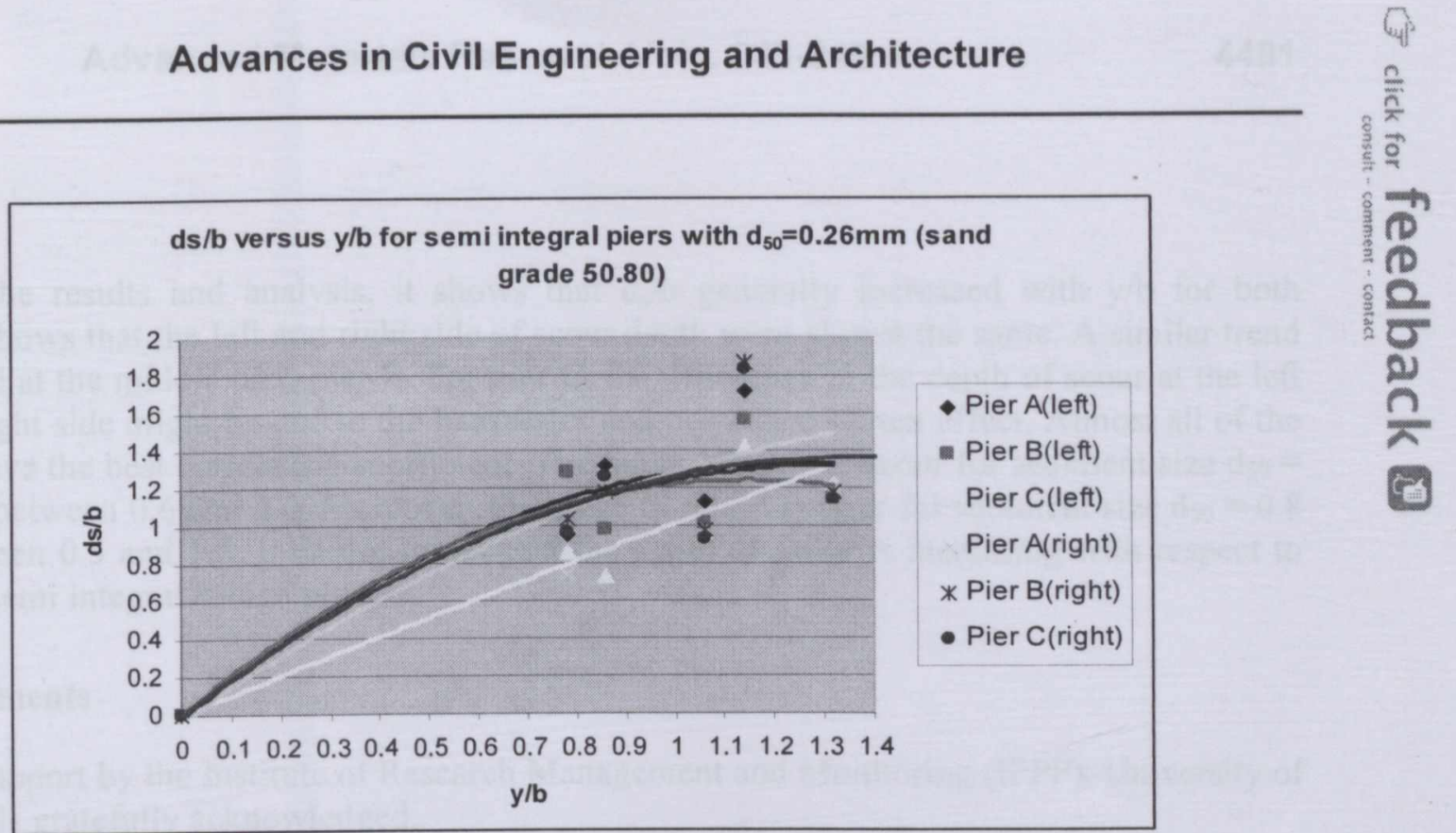

Fig. 3 Effect of flow shallowness on scour depth at semi integral bridge piers for sand of $\mathrm{d}_{50}=0.26 \mathrm{~mm}$.

From Fig. 4, pier $\mathrm{C}$ at the right side of the bridge gives the best correlation compared to other location with correlation coefficient of 0.9019 . At the left and right sides of the front pier that is pier A, relative scour was averaged and the difference in depth of scour was only $2 \mathrm{~mm}$. It shows that the left and right side of scour depth were almost the same. A similar trend was also found at the middle pier, pier B. For pier C, the difference in the depth of scour at the left side and the right side was $4 \mathrm{~mm}$. It was higher than the 2 piers might be due to the backwater effect. The results of the right and left side for every pier were found average. It demonstrates that the depth of scour is increasing with respect to flow depth in semi integral bridge piers.

Similar trend was also produced in the experiment using sediment size of $0.80 \mathrm{~mm}$ with sand grade of 16.30 where the depth of scour increased with the flow depth. Almost all of the data plotted gave the best correlation coefficient. The scour depth at the left and right side of the pier were found to be averaged. In contrast, pier $\mathrm{C}$ at the left side was not in the range. The difference between pier $\mathrm{C}$ at the left and right sides was about $21 \mathrm{~mm}$. It was due to the backwater effect at the pier $\mathrm{C}$. The writer concludes that at both side the scour depth is almost same.

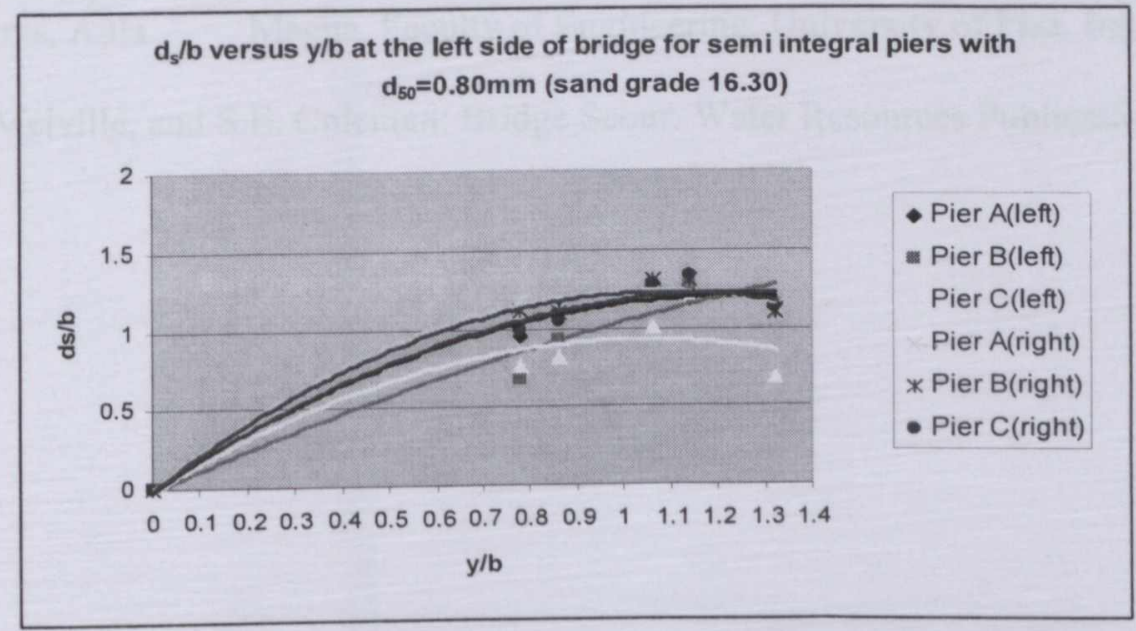

Fig. 4 Effect of flow shallowness on scour depth at semi integral bridge piers for sand of $\mathrm{d}_{50}=0.8 \mathrm{~mm}$. 


\section{Conclusions}

Based on the results and analysis, it shows that $d_{s} / b$ generally increased with $y / b$ for both sediments. It shows that the left and right side of scour depth were almost the same. A similar trend was also found at the middle pier, pier B. For pier C, the difference in the depth of scour at the left side and the right side might be due to the backwater and horseshoe vortex effect. Almost all of the data plotted gave the best correlation coefficient. The range of relative scour for sediment size $\mathrm{d}_{50}=$ $0.26 \mathrm{~mm}$ was between 0.6 and 2.0. Moreover, the range of relative scour for sediment size $\mathrm{d}_{50}=0.8$ $\mathrm{mm}$ was between 0.5 and 1.5 . It demonstrates that the depth of scour is increasing with respect to flow depth at semi integral bridge piers.

\section{Acknowledgements}

Financial support by the Institute of Research Management and Monitoring (IPPP), University of Malaya (UM) is gratefully acknowledged.

\section{References}

[1] A.R. Biddle, D.C. Iles, and E. Yandzio: Integral Steel Bridges: Design Guidance." Steel Construction Institute, ASCOT, Berkshire, UK. Publication No. P162, (1997).

[2] A. J. Raudkivi, and R. Ettema: Scour at Cylindrical Bridge Piers in Armored Beds." Journal of Hydraulic Engineering, ASCE, Vol. 111(4), pp713-731, (1985).

[3] K. H. M. Ali, and O. Karim: Simulation of flow around piers. Journal of Hydraulic Research. Vol. 40(2), pp 161-174, (2002).

[4] S. A. Ansari, U. C. Kothyart, and K. G. Ranga Raju: Influence of cohesion on scour around bridge piers. Journal of Hydraulic Research. Vol. 40(6), pp717-729, (2002).

[5] S. E. Coleman: Clearwater Local Scour at Complex Piers. Journal of Hydraulic Engineering,ASCE. Vol. 131(4), pp 330-334, (2005).

[6] S. Akib, I. Othman, F. Othman, and M. S. Marzuki: Scour at Semi-Integral Bridge Piers and Pile Groups. International Junior Researcher and Engineer Workshop on Hydraulic Structures, Aula Magna, Faculty of Engineering, University of Pisa, Italy, (2008).

[7] B. W. Melville, and S.E. Coleman: Bridge Scour. Water Resources Publication, LLC, (1999). 
Advances in Civil Engineering and Architecture doi:10.4028/www.scientific.net/AMR.243-249

Influence of Flow Shallowness on Scour Depth at Semi-Integral Bridge Piers doi:10.4028/www.scientific.net/AMR.243-249.4478 